\title{
Fossilization of Gender Identities in the Hindu Social Structure: A Study through the Marriage Hymns of Atharva-veda
}

\author{
Dr Pallavi Thakur \\ Assistant Professor, SHSS, Sharda University, Greater Noida, India
}

\begin{abstract}
Ancient Hindu cult adhered to Vedas for the moral and social code of conduct. The tenets of Vedas were treated as sublime, hence were unquestionable. The roots of code of conduct cemented in Vedic India gradually metamorphosed into unequal power distribution in Hindu society. It led to the evolution of sexual identities, along with the customs and practices which emanated gender inequality in ancient India. Established social diktats and process of social conditioning nurtured the gender roles. The paper attempts to examine the marriage hymns of Atharva-veda which delineate roles and responsibilities of men and women in the institution of marriage. The analysis is focused on filtered marriage hymns which discuss the concept of Streedhan, prove the existence of patrilocal and patrilineal society, and advocates motherhood. The objective of the paper is to foresee the impact of the Hindu jurisprudence on its women.
\end{abstract}

Keywords: Female foeticide; male progeny; motherhood; patrilocal; Streedhan 


\section{Introduction}

Vedic period bears a textual legacy which proclaims it as the earliest period in the history of India. Vedic religion had much dissimilarity with Hindu religion, however it is considered as the antecedent of Hindu religion. Hindu scriptures can be classified into two broad categories: Shruti (Heard) and Smriti (Memory). Hindus believe that the eternal truths are omnipresent in the universe. The ancient sages through their meditation understood these eternal truths and preached them orally. It led to the genesis of Shruti texts. Vedas including Rig-veda, Somaveda, Yajur-veda, Athar-veda and Upanishads are a part of Shruti texts. Smriti texts helped Hindus to remember the teachings of Shruti. They act as a source which clarified the revelations made by Shruti texts (Grimes, Mittal \& Thurby, 2006). The remaining scriptures of Hindus are placed under Smriti. Hence Smriti includes: Upavedas, Vedangas, Puranas, Ramayana, Mahabharata, Bhagavad Gita, Dharma Shastras, Agana Shastras, and Bhakti Texts. The texts have a canonical status and are highly revered by conventional Hindus. The abundance of these texts give us access to the then existing philosophy of life.

Because of these circumstances we are in a reasonably good position to study Vedic Hinduism -- we have voluminous texts regarding the religion from various points of view: verbal material internal to the ritual, extremely detailed "handbooks" laying out ritual practice, exegesis of the ritual, both exoteric and esoteric, as well as various views of mythology (Jamison \& Witzel, 1992, p.3).

People adhered to the religious doctrines which taught them the social code of conduct. "It appears to be the case that Hindus do acknowledge the absolute authority of the Veda for legitimizing post-Vedic Hindu beliefs and practices" [Smith, 1998]. The Vedas became the progenitors of various customs, practices and rituals. Hindu jurisprudence evolved and channelized the social structure. It is also notable here that religious schools (śakhas) and dynasties promulgated their own interpretation of the scriptures. Scholars underscore the dynamics of Vedic social system which was not androcentric. According to them women enjoyed all privileges and were at par with men (Ramani, 2015; Kant, 2008; Chakrapani \& Vijay, 1994; Saxena \& Praveen, 2018; Devi \& Kambhampati, 2014; Mahapatra, 2018, Neelam, 2015; Chandrakala et al., 2016). They quote women as philosophers, warriors, sages and also mention women as the composers of several Rig-Vedic hymns. However a dichotomy arises when some scholars negate the existence of an egalitarian Vedic society (Basharat, 2009). Women's status was high but not equal to that of men (Rawat \& Kumar, 2015, p.83). Most of the Indians believe in the myth that Vedic women had a stellar position in the society and their subjugation started with the advent of the Muslim invaders (Bhattacharya, 1992, p.40). Drawing on the scholarship of the exegesis of Vedas, some scholars conclude that women were relegated to a subjugated position.

The laws which degrade women have been in effective operation in Hindu society from the Vedas to the present day and no wonder that a Hindu woman even today is a dwarf compared to her ancient stature given her in early Vedic times (Sharma, 1962, p.41).

Hence a dichotomy exists between Vedic women's stature as liberated or subjugated beings. Existence of women as philosophers, sages and warriors needs to be analysed critically as there is a possibility that these women belonged to a particular caste, class or region or were the enfant terrible. Hence a debate persists among the scholars on the status of Hindu women 
in the Vedic age. However we cannot deny the fact that 'Vedas' are the real identity makers of Hinduism. Though for most of the modern Hindus, Vedic rituals are more or less obsolete due to their enigmatic, expensive and archaic system of application yet the identity of Hinduism generated through it still exists in its social structure. The influence of the preaching of Vedas is such that it has overgrown with time as traditions and customs in Hinduism. We cannot deny the fact that many age-old conventions generated from the Vedic verses still exist in the Hindu society, especially the gender identities. Vedic verses endorse feminine traits in women. Motherhood, docility, subservience, obedience, servility are the different traits endowed to a wife. The custom of patrilocal and patrilineal system in Hindu society and the concept of Streedhan also articulated and propagated through it which have assimilated in the Hindu social structure. These are woven in the Hindu social structure and are now claimed as religious and cultural heritage. The analysis of the 'Marriage Hymns' of Atharva-veda gives us a better understanding of the gender identities created in the Vedic age. "The exact details of the Vedas role in this suppression have never been made clear" (Leslie, 1992, p.18). Hence an effort is made in this paper to analyze the hymns of Atharvaveda in context to Hindu women's preordained secondary status in the society. The paper examines the marriage hymns of Atharva-veda to illustrate that patriarchy and the masculine interests are fortified and emanated from the fundamental teaching of the hymns.

\section{Methodology}

The present paper focuses on the filtered marriage hymns of Atharva-veda, Khand (Part) 14, which expound the ideology of patrilocal and patrilineal society and the concept of Streedhan. T.H. Ralph Griffith translated the Sanskrit hymns of Atharva-veda and compiled them in his book Hymns of the Atharvaveda (1895). The Sanskrit translation of the hymns quoted in the paper is extracted from Griffith's book. An attempt is made to examine the role of these injunctions in rendering a marginalized and subordinate position to women in Hindu society. The analysis would also assist in identifying the beliefs, norms and customs established by the religious scriptures, like Atharva-veda, and its implications on the modern Hindu women. Various survey reports have been used to substantiate the challenges faced by modern Hindu women.

\subsection{Hymns of Atharva-veda Advocating Patrilocal Society}

Marriage hymns of Atharva-veda underscore the canonical status of patrilocal system of marriage in Vedic age. The hymns propound the migration of married girls to matrimonial family. A woman's life gets circumscribed by stigma if she stays at her natal home after marriage in Hindu society. Life of a woman has two hemispheres which are broadly classified as childhood and adulthood. Once she steps into the matrimonial family, her whole life becomes associated with it. Many scholars concur that in Hindu society a woman spends "the early years at her father's house and after puberty, in later periods even before puberty, she was given in marriage and passed the rest of her life at her in-law's house. A married woman was not supposed to return to stay at her parent's house under any circumstances because it would give rise to scandal. Authors of the Vedangas - which are quite late textsstrongly condemn her return" (Bhattacharya,1992, p.43). Marriage, as mentioned by Atharvaveda, expects a woman to detach from natal home and homogenize with the matrimonial family by catering to all their needs and desires. However, this assimilation erases the identity of a girl which she owns since her childhood. "Parents experience the marriage of their 
daughter as "losing" her to another family..." (Uma, 1993, p.163). Hymn XVII of Book XIV beseeches:

Worship we pay to Aryaman, finder of husbands, kindly friend.

As from its stalk a cucumber, from here I loose thee, not from there (Griffith, 2009, p.130).

The hymn disjoints a woman from her parental home and conjuncts her with groom's family after marriage. It asserts that as a cucumber, when ripens, is separated from its stalk, similarly a woman is uprooted from her parental home after the consummation of marriage. It clearly exhibits that a woman is denied the right to her parents after marriage. Women were expected to merge their identity with that of the matrimonial family and forsake their roots.

"Women are expected to leave their natal homes at marriage to live with the family of the groom, to whose customs they are expected to adapt" (Shenk, 2007, p. 244). Such conceptions made people perceive daughters as a liability till they are bequeathed to the groom. The tenet fossilized in the ancient Hindu social structure and became the social code of conduct which weakened the position of women in the society. This Vedic prescription is still influential in modern India. Even today marriage uproots women from natal family and implants them in the matrimonial family. They recreate their identity according to the expectations of husband and his family. At this stage of their life they become a female completely by imbibing the roles ascribed to the married women. Trying to fit into different roles attributed to her after marriage, women learn to self-abnegate and neglect their true self.

\subsection{Hymns of Atharva-veda Cementing the Concept of Patrilineal Society}

The Hindu scriptures and mythology mostly portray women as wife, mother and beloved. The common characteristics of these womanly roles are self-abnegation, docility, servility to men and their family, dexterity in managing home and relations. The most important duty of a wife is to bestow the matrimonial family with a son. Oldenberg has quoted several examples from Vedas where a number of methods have been suggested to procure a son. Oldenberg quotes one such example, "At the ceremony to get male progeny, the woman has to eat a barley corn and two mustard seeds or beans placed on both sides of the barley corn and an image of the male genital organ so that she may give birth to a male child" (Oldenberg, 1993, p.262). Hymn XVIII of Book XIV enforces patrilocal and patrilineal concept of society:

Hence and not thence I send her free. I make her softly fettered

there.

That, bounteous Indra! She may live blest in her fortune and her sons (Griffith, 1895, p. 130).

The above hymn too sets the bride free from her parental home and unifies her to the groom's. It hails Indra to bless the bride with fortune and sons. The hymn exhibits the society's preference for a male progeny and enforces the ideology of motherhood. Hence besides being a wife, another role set for a woman is motherhood in the institution of marriage.

Myriad hymns of Atharva-veda request the deities to bestow motherhood on the bride. A perusal of various ancient texts indicates that there has never been a time when women's labour at home, however heavy, was regarded as productive. Women's sole worth lay in their reproductive role in the absence of which they could be disowned by the family which had the consent of the society and approval of the scriptures. (Bhattacharya, 1992, p.51). Motherhood 
grants admiration and high status to women in the Hindu society. It is considered as one of the prized womanly traits in a female and provides an easy admission to women in the fraternity of mothers. "Since a major aspect of the female role is considered to be reproduction, motherhood has continued to be basic to women's lives as well as the organization of the family, and is fundamental to the genesis of the ideology about women. Symbolized in mythology, legends and popular culture, she stands as an eternal icon to represent the generative, nurturing power of life, itself celebrated in temples and sculptures, poetry and literature" (Maithreyi, 2010, p.1).The ancient notion of the Hindu society which circumscribes women's life with marriage and motherhood is still rampant in contemporary society. Women are viewed as blessed with reproductive mechanism and hence it is considered as their foremost duty to provide a male offspring to ensure continuity of family lineage. Vedas disseminated obsession for sons. The ancient texts beseech to grant sons and not daughters in a family. The preference to sons is as old as Indian society itself. Vedic verses pray to have more male offspring and not the daughters (Kakar, 2012, para3). A major section of the Hindu populace still treats boys as the harbinger of fortune and despises the presence of a girl. As a result, the male child has become a welcome reprieve to the families as he provides support to the parents in old-age and extends family lineage. The urge to have a son was so intense in Hindu families that many mismatched marriages were consummated in order to maintain family lineage. Old men started marrying young girls of 15 to 16 years to maintain family lineage through male offspring (Misra, 1992, p.3). Whereas, a girl-child is treated as a burden as she has to be brought up and given to another family along with monetary assets. The connubial family expects the bride to provide them with a male progeny who will be the carrier of their family lineage.

In most cases, especially in rural regions of India, women do not undertake maternity in freedom. Majority of modern Hindu women face the trauma of forced motherhood. Family's pressure for providing a male progeny makes them accept undesirable motherhood. Maternity has also become a challenge to the working mothers as they find it difficult to maintain equilibrium between the child and their career. Upbringing of a child is still looked upon as a feminine attribute hence it still rests in the hands of mothers. Hymn XIV of Book XIII states:

No slayer of thy husband or his father, gentle and bright, bring blessing on the cattle.

Loving thy husband's father, bring forth heroes. Tend well this

household fire: be soft and pleasant (Griffith, 2009, p.141).

The hymn mentions the characteristics to be possessed by women after marriage. It includes: catering to the needs of their family, providing male offspring, being soft and docile to the family members and manage the household affairs with dexterity. Some Hindu women endorse feminine traits as their identity whereas others choose it out of social compulsion. Majority of Hindu women, especially those belonging to rural regions of India, play no role in the decision-making of the family or society. They had "minor role in the formulation and development of social, religious and philosophical thinking. Whatever instincts they have had historically towards these activities have been suppressed. Among the usual suspects charged with the responsibility for the suppression, the Veda and Vedic religion stand out. " (Leslie, 1992, p.18). The division of the society on the basis of gender since Vedic age cannot be denied. It's appalling to see Atharva-veda laying the foundation of gender roles in the Vedic 
society. The defined roles of women are not in concurrence with their ability to develop as an individual. Shashi Deshpande elucidates in No Man is an Island:

I believe that the family is not a divine sacred institution, but one created by human beings for the benefit of the society; and therefore, it should be built, not on the sacrifice of some, but on the co-operation and compromises of all its members. The loud cry of the new-born is a triumphant assertion of being-I AM. Does a baby girl cry less loudly? (Deshpande, 2001)

Since Vedic period women's workplace has been her home. These imprints of ancient social code of conduct given by the Hindu religious precepts have been passed to generations. Despite being educated and economically independent, women's 'ancient 'workplace' is still limited to her and has not reached to her spouse or family. Shashi Deshpande reiterates her views on modern women's growing dilemma as education and financial stability is not assisting them to unleash from the conventional traits. She states that education and economic independence can be treated as tools. A woman can be educated and economically independent and still be wrapped by conventional norms of the society. Self-abnegation helps women in realising their roles and responsibilities towards their families. (Thakur, 2009, p, 230). The dichotomy between conventional societal roles and modern outlook gained through education and economic independence has left the modern Hindu women perplexed. It has been observed that women are using opportunities to fulfil the traditional requirements and not to bring changes in the social norms which stifle them (Lau, 2006, p.169).

\subsection{Hymns of Atharva-veda on Streedhan}

An explicit definition of Streedhan has not been given by any of the religious Hindu texts. However, as the word is composed of 'Stri' (woman) and 'dhan' (property), conjunctively it suggests 'property of woman'. References of Streedhan have been made in Atharva-veda. The term Streedhan means the gifts given to the bride by family and friends at the time of marriage. This bride's wealth can be divided into three categories: 'pana' which is used to purchase the bride; 'yautaka', gifts given to the girl by her relations and friends at marriage and 'saudayika', gifts received by bride or the couple either at bride's or at groom's place (Bhattacharji, 1991, p.507). Many hymns of Atharva-veda discuss streedhan being carried in chariots after marriage from bride's home to groom's family. Griffin has used several terms for streedhan in his translation of the hymns from Sanskrit to English. He calls it as 'bridal pomp', 'bridal train', 'nuptial pomp' and 'bride's procession'. The following hymn II (XIII, Book XIV) explicitly mentions streedhan being taken to the groom's family:

The bridal pomp of Sūryā, which Savitar started, moved along.

In Maghā days are oxen slain, in Phalgun is they wed the bride (Griffith, 1895, p.130).

The 'bridal pomp of surya' signifies the gifts given to the bride during marriage. It says that the gifts were sent to the groom's home before Surya (the bride) had left her parental abode. Cows were sent in 'Maghā' whereas bride was sent during 'Phalgun'. 'Maghā' and 'Phalgun' are the names of the months as per the Hindu calendar. The sutra clearly shows that cows were a part of streedhan. Domestic animals were an important part of a family in ancient India. They were reared to procure animal products which were among the necessities of their life. Hence the sukta mentions cows as a part of 'bridal pomp'. Many interpretations have 
been given by the scholars to the concept of Streedhan. Some believe that it only meant the gifts given to the bride by friends and relatives i.e. 'yautaka' or 'shudayika' and does not stand for dowry. It was not imposed on the bride's family by the groom's, in order to materialize the marital alliance. Whereas some believe that it was a kind of dowry, as the gifts given to the bride were taken as an asset by the groom's family. Existence of streedhan in Vedic age is palpable through the hymns of Atharva-veda. Hymn II(I) of Book XIII addresses streedhan as 'bridal train'. It also re-enforces the idea of motherhood and male progeny. The analysis of Hymn II (I), Book XIII confirms that Atharva-veda advocates streedhan and upholds patrilineality:

For thee with bridal train they first escorted Sūryā to her home,

Give to the husband in return, Agni, the wife with future sons (Griffith, 1895, p.139).

The hymn states that the bride is escorted to her husband's home along with 'bridal train' (streedhan). She will soon be the blessed wife bestowed with 'future sons'. The entire hymn exhibits woman as a marginalized being as she is being viewed only as a wife, a mother and a harbinger of prosperity because of the wealth brought by her. Atharva-veda has orchestrated and limited a woman's role to domestic life in marriage. She is born to serve, bring fortune and continue the process of human proliferation. Gender discrimination seems to be rampant which stratified the society and gave patriarchy a promising position in the social structure. The following hymn too discusses streedhan given to the bride during the nuptial bond. It requests the common folk not to destroy the chariot which carries the streedhan (nuptial pomp). Book 1, Hymn II (IX) of Atharva-veda instructs the matrimonial family:

Here these my words, ye men, the benediction through which the wedded pair have found high fortune.

May the divine Apsarases, Gandharvas, all they who are these fruitful trees' protectors

Regard this bride with their auspicious, favour, nor harm the nuptial pomp as it advances (Griffith, 1895, p. 140)

Atharva-veda also opines the groom's family to accept streedhan and not to scrutinize it. It appeals to Savitar to make it pleasurable and enjoyable to the couple and specifically mentions the commodities useful for the couple's domestic life. This clearly reflects the existence of a custom where the brides carried with them gifts for matrimonial family. Women appear to be financially unproductive in ancient India. They were more of a domestic help whereas men were the bread earners. Hence migration of a girl from natal to the matrimonial family meant a life-long liability to the latter. They had to provide food, shelter and clothing to the girl for the rest of her life. Hence it was expected of her to carry streedhan (land, gold, utensils, domestic animals, clothing etc.) which was treated as a rational investment made by the bride's family in exchange of their daughter. Hence streedhan, which most researchers believe as a mode of 'female inheritance', was more of an economic gain to the groom and his family. Kishwar points out:

In actuality, a woman is seldom allowed to have control even over things that are supposedly for her personal use. Gold and other jewellery are traditionally supposed to be a woman's personal security, but, in practice, the gold usually stays in the custody of her mother-in-law or husband. It is up to them to give her 
what they wish for her personal use and daily wear . . . It is fairly common for certain items of her jewellery to be incorporated into her husband's sister's dowry (Kishwar, 1986, p.7).

The ancient concept of streedhan seems synonymous with 'dowry' which has become a menace in the contemporary Indian society. Myriad hymns of Atharva-veda repeatedly request the groom and his family to accept streedhan. Hymn II (XII), Book 1:

I look upon the house and bride's procession with prayer and with the gentle eye of friendship.

All that is covered there in perfect beauty may Savitar make pleasant to the husband (Griffith, 1895, p. 139).

The hymn prays that may the 'bride's procession', i.e. streedhan, be safe and appeal to groom. It endorses the gifts brought by the bride and describes it as 'all that is covered in perfect beauty'. It beseeches Savitra to bestow his blessings on the streedhan and make it pleasant to the groom. Streedhan is sanctified by Atharva-veda as it resonates in most of its marriage hymns. Many researchers believe that streedhan was given for assistance to the bride or to equip her with the right to property but the custom clearly confirms the existence of gender inequality as the burden of sending gifts was on the bride's family and not on the groom's. This exposes the vested interests of the patriarchal society which made a huge profit through the matrimonial alliance. Moreover, the marriage hymns of Atharva-veda nowhere encourage the matrimonial family to accept the bride without streedhan.

\section{Transition in the life of Hindu women due to Religious indoctrinations \\ 3.1 Dowry Substituting Streedhan in Modern India}

Streedhan as mentioned in Atharva-veda and other Hindu scriptures deformed with the passage of time and metamorphosed into dowry. The modern Indian society uses the custom to accumulate wealth and reputation. In all matrimonial alliances it is understood that besides dowry the bride's family would also bear the burden of the entire expenditure of marriage. It has transformed matrimony into a business agreement in which the more one pays the better groom one gets. The more educated the woman, the more educated her potential partner ought to be and thus the higher the 'price' he commands in the negotiation process (Channa, 1991, p.369). Dowry has put a question on women's integrity as no matter how qualified a woman is still her family has to pay dowry during her marital alliance. The desire to procure more wealth in the form of dowry has increased manifolds in the Hindu society. Though prohibited by the judicial system of India, dowry is still rampant in the country.

The common tradition in the Indian Hindu society of gifting household articles to their daughter on her marriage has begun to take the shape of the obnoxious dowry practice due to greed and male chauvinism. This practice of dowry today has ransacked every aspect of morality taking toll on innocent girls in the form of dowry torture in general and dowry death in extremes (Mohanty et al., 2013, p.316). It has led to increase in crime against women in India. Bride-burning, domestic violence, sexual exploitation, female foeticide and infanticide are the offshoots of dowry. These cases are not limited to Hindu society but are also reported in other religions of India. A report, 'Crime in India', gives the data on, Cruelty by husband or his relatives (Section 498-A IPC) (Incidence: 1,22,877 Rate: 20.5). A total of 1,22,877 cases were reported in the country during the year 2014 showing an increase of $3.4 \%$ over 2013 
$(1,18,866$ cases) and an increase of $20.9 \%$ over the average of last 5 years (2009 - 2013). $18.9 \%$ of such crimes in the country were reported from West Bengal alone (23,278 cases) followed by $12.9 \%$ in Rajasthan (15,905 cases) and $8.5 \%$ in Uttar Pradesh (10,471 cases)( Crime in India, 2014, p.32 ).

Dowry is no more a custom rather it has become mandatory to consummate a marriage. "What might have been, in an earlier time, a means of economically empowering a woman at the time of marriage, has metamorphosed in many cases into an instrument of exploitation of the bride's family by the groom and/or his family" (Belur et al., 2014, p.2). None of the dowry goes directly to the woman, who becomes increasingly defined as a means by which to obtain cash (Rudd, 2001, p.517). Most of the marriage proposals are rejected by the groom's family as they are not able to meet their expectations. Streedhan, which has now been transformed into dowry, is culpable for perpetuating patriarchy and female subservience. It has led to an unequal distribution of power between men and women.

"Over the last two decades, the reports from India have shocked the world: married women murdered (usually burned to death) by their husbands and/or in-laws over the issue of inadequate dowry. These recent incidents of bride burning are a shocking example of the new forms of violence against women which are arising in modern, or modernizing, settings in many areas of the world" (Stone \& Caroline James, 1995, p.125). Dowry Prohibition act implemented in 1961 was amended in 1986 in order to deal with this menace stringently. However, a report, 'Crime in India 2014' shows an alarming increase in dowry deaths in some of the states of the country. The highest number of cases of kidnapping \& abduction of women $(10,626$ cases) and dowry deaths $(2,469$ cases) were reported in Uttar Pradesh, accounted for $18.5 \%$ and $29.2 \%$ of total such cases respectively (Crime in India, 2014, p.2).

Table [1] exhibits an increment in dowry deaths with the passage of time in India. Incidence of Cognizable Crimes (IPC) Under Different Crime Heads During 1953 to 2014:

\begin{tabular}{|r|c|c|}
\hline S1.No. & Year & Dowry Deaths \\
\hline 43. & 1995 & 4648 \\
\hline 53. & 2005 & 6787 \\
\hline 62. & 2014 & 8455 \\
\hline
\end{tabular}

Table [1]: National Crime Records Bureau. Crime in India 2014. p.12.

The dowry deaths have almost doubled in the period of 1995-2014. The table exhibits the despicable condition of women in modern India due to dowry. As per the report given by the National Crime Records Bureau (NCRB) 2008, the percentage of dowry deaths is very high in some states of India. Table 146 of the highlight Uttar Pradesh, Bihar, Madhya Pradesh, Rajathan as the states of India where the cases of dowry death are quite high.

\subsection{Female Infanticide and Sex-Selective Abortion}


The society's discriminatory attitude towards girls and the incessant burden of dowry have become the genesis of female infanticide and sex-selective abortion in India. "The two are similar in that they both eliminate female babies but there are, however, distinct differences. The differences in these acts are self-explanatory, and the practices are defined, in many cases, by class. In both cases, the motivation is that the economically excruciating demand for dowry (to obtain a marriage for their daughter as well as meet the continual demand of her inlaws), is simply too much of a burden for a girl's family to handle" (Petrazzuolo, 2012, p.60). The incidents of killing a female embryo or a female baby or disowning a female child have escalated in India. Most of the orphanages find baby girls as the abandoned child.

Female infanticide is commonly practised in the rural India where people are more conventional and traditional. The social compulsion on women to produce sons pervades female infanticide. Dowry has subjected women to a mortal danger since their birth. Many surveys have proven that sex-selective abortion has increased manifolds with the passage of time in the country. The following table discusses the sex ratio in the year 2000-2002. 


\begin{tabular}{|c|c|c|c|}
\hline \multicolumn{4}{|c|}{$\begin{array}{c}\text { Table } 1 \text { : Sex Ratio (females per } 1000 \text { males) } \\
\text { at Birth, 2000-2002 }\end{array}$} \\
\hline India/States & Rural & Urban & Total \\
\hline (1) & (2) & (3) & (4) \\
\hline INDIA & 898 & 868 & 892 \\
\hline Punjab & 781 & 757 & 775 \\
\hline Haryana & 817 & 745 & 804 \\
\hline Himachal Pradesh & 826 & 826 & 826 \\
\hline Uttar Pradesh & 862 & 875 & 864 \\
\hline Gujarat & 866 & 788 & 844 \\
\hline Rajasthan & 886 & 917 & 890 \\
\hline Bihar & 870 & 863 & 870 \\
\hline Maharashtra & 904 & 891 & 899 \\
\hline Kerala & 913 & 904 & 911 \\
\hline Madhya Pradesh & 933 & 849 & 920 \\
\hline Andhra Pradesh & 939 & 967 & 945 \\
\hline Tamil Nadu & 946 & 883 & 926 \\
\hline Assam & 947 & 913 & 945 \\
\hline Orissa & 950 & 889 & 944 \\
\hline Karnataka & 950 & 957 & 952 \\
\hline West Bengal & 957 & 915 & 949 \\
\hline $\begin{array}{r}\text { Note: The states ar } \\
\text { Birt }\end{array}$ & $\begin{array}{l}\text { in orde } \\
\text { 2) }\end{array}$ & Sex re & \\
\hline
\end{tabular}

Table [3] Registrar General, India, Sample Registration System, Statistical Report, 2002, New Delhi, 2004, p.31.

The sex ratio of India reveals the decline in the birth of girls in both rural and urban India as compared to that of boys'. Sex detection test has been banned in India since 1977. Still the statistics exhibit the difference in the sex ratio in India which makes a mockery of the Indian government's miserable failure in eradicating female foeticide. It also clearly shows that a major section of Indian society desires a male progeny instead of a female child. As all the religions which thrived on the Indian soil grew with the existing social norm, customs and traditions, they too imbibed them in some ways. The above statistics is not limited to Hindu society but exhibits contemporary Indian society as a whole. However the data should be 
assessed by keeping in mind that Hindus form the major section of Indian society as Sikhism, Jainism and Buddhism are also a part of Hinduism. Christianity and Islam grew on the soil of India, through the migrants who settled in the country or due to the mass conversions of the natives, also imbibed many Hindu customs and traditions. Dowry and its repercussions ensnare women as a whole in contemporary India. Hence the data reflects more on Hinduism than any other religion of India.

Dowry is creating undue pressure not only on the parents but also on the girls. Many cases have cropped up which narrate the incidents where the girls committed suicide to relieve their parents from the burden of dowry. One such case "that received national attention in the Indian press involved the triple suicide of the three sisters in the industrial city of Kanpur. A photograph was widely published showing the three young women hanging from the ceiling fans by their scarves. Their father, who earned about $4000 \mathrm{Rs}$, per month, was not able to negotiate..." (Channa, 1991, p.369). Financial constraints make the parents incapable to find a suitable match for their daughters. Grooms now expect their brides to be well-educated so that they would share the financial responsibilities of their family in future. Hence the girl's parents now have dual responsibilities, they are expected to educate the girl and also pay dowry. The obnoxious practice of dowry, which has a close association with streedhan, has denigrated the status of women in modern India.

The analysis of Atharva-veda leads to the following conclusion: the hymns related to the roles and responsibilities of women in matrimony are discriminatory in nature and marginalize them. Marriage is the only goal set for women. Women have limited roles assigned to them in the institution of marriage and are addressed only as a wife, mother and daughter-in-law. Her world is her home and her duties are subjected to family. She is expected to provide a male progeny to the family in order to continue the family lineage. This proves that Atharva-veda gives higher value to men by birth. It can also be firmly stated that Atharva-veda advocates streedhan as most of the marriage hymns resonate it. The analysis of the hymns confirms the discriminatory verdict of the patriarchal Hindu cult. Streedhan has become a focal point from which various malpractices against women have evolved. Dowry, dowry deaths, female foeticide, female infanticide, and declining sex ratio are the offshoots of streedhan which are proving fatal for modern Hindu women. Though the government of India has taken certain stringent measures to curb the problem yet its materialization at social level is still a remote dream.

\section{Conclusion}

Religion and society constitute identities of people. Religious discourse, symbols, stereotypes, and networks contribute in instituting the identities. Religious scriptures, like Vedas, embellish women with feminine traits. The contemporary Hindu society needs to critically evaluate the biased indoctrinations cradled by it since ages. Unless and until such indoctrinations are eliminated from the society, Hindu women would continue to remain suppressed because the existing discrimination against females would amplify the dichotomy between men and women at social level with the passage of time. The paper attempts to unveil the despicable status of contemporary Hindu women in India, who despite being educated and economically independent are unable to liberate from the conventional social codes. Hindu women have achieved political, economic and constitutional liberty in India but 
they have yet to achieve the social liberty. Marriage is still considered as the only way to become a respectable member of the society for Hindu women and empowers them to exist as social beings.

Hindu social structure established centuries ago still see men as guardians of women. Guided by a set of normative rules and idealized gender roles, hymns of Atharva-veda prove a testimony to the existing patriarchy in the Hindu society. The solidified patriarchal, Vedantic view has created a schism in the society which is difficult to coalese even though Hindu women have gained education, economic independence and constitutional rights.

\section{References}

Basharat, Tahira. (2009). The Contemporary Hindu Women of India: An Overview. A Research Journal of South Asian Studies, 24(2), 242-249.

Belur, Jyoti, Nick Tilley, Nayreen Daruwalla, Meena Kumar, Vinay Tiwari, David Osrin. (2014). The Social Construction of 'Dowry Deaths. Social Science \& Medicine, 119, 1-9.

Bhattacharya, Sukumari. (1992). The Position of Women in Vedic Society. India International Centre Quarterly, 19(4), 40-52.

Bhattacharji, Sukumari. (1991). Economic Rights of Ancient Indian Women. Economic and Political Weekly, 26(9), 507-512.

Brewer, P. (2004). Frederick Engels, The Origin of the Family, Private Property and the State, Introduction by Pat Brewer. Retrieved from http://readingfromtheleft.com/PDF/EngelsOrigin.pdf

Chandrakala, S. Halli \& Shirdhar M. Mullal. (2016). Status of Women in India. Imperial Journal of Interdisciplinary Research, 2(2), 297-300.

Chakrapani, C. and Vijay Kumar S. (1994). Changing Status and Role of Women in Indian Society, New Delhi: M.D. Publications.

Channa ,V. Willigan. (1991). Law, Custom, and Crimes against Women: The Problem of Dowry Death in India. Hum. OrganI, 50, 369-377.

Deshpande, Shashi. (2001). No Man is an Island. The Times of India. Retrieved from http://ch.8m.com/cgi-bin/framed/1179/shashi.htm

Devi, Naroem Jiteshwari \& Kambhampati Subramanyam. (2014). Women in the Rig Vedic Age, International Journal of Yoga-Philosophy, Psychology and Parapsychology, 2(1), 1-3.

Grimes, J., Sushil Mittal, and Gene Thursby. (2006). Hindu Dharma. In Sushil Mittal and In Gene Thursby (Ed.), Religion of South Asia: An Introduction (pp.35-36). New York: Routledge.

Hymns of the Atharvaveda. (1895). Trans. T.H. Ralph Griffith, Book XIV. Hymn I. Retrieved from http://www.sacred-texts.com/hin/av/av14001.htm

Hymns of the Atharvaveda. (1895). Trans. T.H. Ralph Griffith, Book XIV. Hymn II. Retrieved from http://www.sacred-texts.com/hin/av/av14002.htm 
Jamison, S.W. and M.Witzel. (1992). Vedic Hinduism. Retrieved from http://www.people.fas.harvard.edu/ witzel/vedica.pdf

Kakar, Sudhir. (2012, 12 October). The Inner World: A psychoanalytic study of childhood and society in India. Through your own eyes. In Arun Ganpathy (Ed). Retrieved from speakingtree.in/article/through-your-own-eyes

Kant, Anjali. (2008). Women and the Law. A.P.H. Publishing House: New Delhi.

Kishwar, Madhu. (1986). Dowry: To Ensure Her Happiness or to Disinherit Her. Manushi 34, 2-13. Retrievd from http://www.manushi-india.org/pdfs_issues/articles/Dowry-to\%20ensure23.pdf

Krishnaraj, Maithreyi. (2010). Motherhood in India: Glorification without Empowerment. Routledge: Noida. 1-8.

Lau, Lisa Ee Jia. (2006). The New Indian woman: Who is she, and what is "New" about her? Women's Studies International Forum, 29, 159-171.

Leslie, Julia. (1992). Roles and Rituals for Hindu Women (17-43. ). Motilal Banarsidas: Delhi.

Mahapatra, Atri. (2018). Gender Equality and Ancient Indian Culture: A Study. International Journal of Humanities and Social Science Innovation, 7(8), 22-26.

Mary K, Shenk. (2007). Dowry and Public Policy in Contemporary India: The Behavioural Ecology of a Social Evil, Hum Nat, 18, 242-263.

Misra, Lakshmi. (1992). Women's Issues: An Indian Perspective. Northern Book Center: New Delhi. 1-8.

Mohanty, S., Mousumi Sen \& Geeta Sahu. (2013). Analysis of Risk Factors of Dowry DeathA South Indian Study. Journal of Forensic and Legal Medicine. 20. 316-320.

Narayan, Uma. "Paying the Price of Change: Women, Modernization and Arranged Marriages in India, Turshen," in Women's Lives and Public Policy - The International Experience, ed. Meredith, Turshen and B. Holcombe (Connecticut: Greenwood Press, 1993): 159-70.

National Crime Records Bureau. Ministry of Home Affairs. (2008). Crime in India. New Delhi. 387-392.

National Crime Records Bureau. Crime in India. (2014). New Delhi. Government of India. 17 .

Neelam. (2015). Socio-Economic, Religious, Educational, Domestic and Political Rights to Women in Ancient India. International Journal of Humanities and Social Sciences. II(III), 111-117.

Oldenberg, Hermann. (1993). The Religion of the Veda. Shridhar B. Shrotri(Trans.), Delhi: Motilal Banarisdass. 251-269.

Rudd, J. (2001). Dowry-Murder: An Example of Violence against Women. Women's Studies International Forum, 24, 513-522.

Saxena, Govind Kumar \& Praveen Kumar Sharma. (2018). Position of Women in Vedic, Post-Vedic, British and Contemporary India. The International Journal of Legal Developments and Allied Issues. 4(4). 372-380. 
Sharma, I.D. (1962). Western Ideas and the Awakening of Indian Women. East and West 13. 41-48.

Smith, K Brian. (1998). Reflections on Resemblance, Ritual, and Religion. Delhi: Motilal Banarsidass.

Stone, Linda and Caroline James. (1995). Dowry, Bride-burning, and Female Power in India. Women's Studies International Forum, 18, 125-134.

Petrazzuolo B.S. (2012). Dowry-Murder, Female-Infanticide \& Sex-Selective Abortions in Northern India (Master's Thesis). Georgetown University Washington, D.C.

Thakur, Pallavi. (2009 ). The Fiction of Shashi Deshpande: Women's Journey from SelfEffacement to Self-Actualization. In R.K.Dhawan (Ed.), Feminism and Recent Indian Literature (pp.228-262), Prestige Books: New Delhi. 